\title{
THE ROLE FINANCIAL LITERACY AND FINANCIAL PLANNING TO INCREASE FINANCIAL RESILIENCE : HOUSEHOLD BEHAVIOUR AS MEDIATING VARIABLE
}

\author{
Noni Setyorini \\ Universitas PGRI Semarang \\ Email: nonisetyorini@upgris.ac.id (corresponding author) \\ Rr Hawik Ervina Indiworo \\ Universitas PGRI Semarang \\ Email: indiworo1983@gmail.com \\ Sutrisno \\ Universitas PGRI Semarang \\ Email: sutrisno60upgris@gmail.com
}

Received: May 2021; Accepted: June 2021; Available online: July 2021

\begin{abstract}
This study aims to examine the effect of spatial literacy and financial planning by using household behavior as a mediator. The testing uses a mediation process using Smart PLS 3.0. Respondents were collected using an online survey using a simple random sampling technique. The number of respondents used in this study was 102 respondents. Based on the results of data processing, financial literacy on financial resilience is not supported. Meanwhile, the effect of financial literacy on financial resilience by mediating household behavior is accepted. The hypothesis of financial planning on financial resilience is not supported. However, the effect of financial planning on financial resilience with household behavior as mediation is supported. This research provides theoretical and practical contributions which will also be discussed further in this paper.
\end{abstract}

Keywords: financial literacy; financial planning; financial resilience; household behavior.

\begin{abstract}
Abstrak
Penelitian ini bertujuan untuk menguji pengaruh literasi keruangan dan perencanaan keuangan dengan menggunakan household behavior sebagai pemediasi. Adapun pengujian menggunakan proses mediasi menggunakan Smart PLS 3.0. Pengumpulan responden dilakukan dengan menggunakan online survey menggunakan teknik simple random sampling. Jumlah responden yang digunakan dalam penelitian ini adalah 102 responden. Berdasarkan hasil pengolahan data literasi keuangan terhadap ketahanan keuangan adalah tidak didukung. Sedangkan pengaruh literasi keuangan terhadap ketahanan keuangan dengan mediasi household behavior adalah diterima. Hipotesis perencanaan keuangan terhadap ketahanan keuangan adalah tidak didukung. Namun pengaruh perencanaan keuangan terhadap ketahanan keuangan dengan household behavior sebagai pemediasi adalah didukung. Penelitian ini memberikan kontribusi teoritis dan praktis yang juga akan dibahas lebih lanjut dalam makalah ini.
\end{abstract}

Kata kunci: literasi keuangan; perencanaan keuangan; perilaku rumah tangga; ketahanan keuangan.

How to Cite: Setyorini, N., Indiworo, R. H. E., \& Sutrisno (2021). The Role Financial Literacy and Financial Planning to Increase Financial Resilience: Household Behaviour as Mediating Variable. Media Ekonomi dan Manajemen, 36(2), 243255. doi: http://dx.doi.org/ 10.24856/mem.v36i2.2179. 


\section{INTRODUCTION}

A virus began to spread that caused an unknown pneumonia disease that started in Wuhan, Hubei Province in early 2020. The virus spread rapidly to more than 190 countries and regions. The virus is called coronavirus-2 (SARS-CoV-2) which causes coronavirus disease 2019 (COVID19), which causes severe acute respiratory infections. The spread of this disease not only has an impact on health but also has a broad social and economic impact (Susilo et al., 2020). Based on these problems, humans are faced with various kinds of things that must be faced, such as the threat of losing their jobs, debilitating diseases, injuries or the cost of large houses or cars, or worsening economic conditions due to the Covid-19 pandemic which disrupt financial stability. Therefore, it is necessary to have financial resilience in order to withstand the bad economic conditions and life tests. The purpose of this study is to increase public financial resilience when facing various financial problems that arise, especially in the face of the Covid-19 pandemic.

Financial resilience is defined as the ability to withstand life events that have an impact on a person's income and / or assets (Klapper \& Lusardi, 2020). Suarez, (2015) have examined the financial resilience of the national economy. They argue that the more resilient the economy is the better it is at dealing with crises. They introduce two dimensions of financial resilience that can be applied to (local) government as well. The first dimension of financial resilience is the ability to overcome the impact of financial shocks. Second, financial resilience is not only about the ability to cope with financial shocks, but also some capacity to react adequately and implement policies quickly (Suarez, 2015).

Financial resilience has great benefits in facing a crisis. However, to be able to withstand a crisis one must have the ability to plan and manage finances properly. In addition, good financial knowledge is also needed so that financial management can be better by placing money in accordance with appropriate items (Barbera et al., 2017). Bieri (2014) states that families must be able to cope with an increasingly complex economy. The threat of persistent recession, easy access to credit or debt, unpredictable oil and fuel prices, changes in public policy, and so on. Hakim et al., (2014) states that financial management is a family activity in planning, organizing, implementing, and controlling family finances and assets. According to Firdaus (2018), family financial management includes communication in using income. Family financial management aims to use personal and financial resources to produce a level of life satisfaction and build financial reserves to meet future and sudden needs (van Rooij et al., 2012).

Surprisingly, little research attention has been devoted to this topic despite the fact that personal finances influence everything we do as consumers. It determines household buying power and influences day to day decisions such as eating out, retail store selection and paying by cash or credit; strategic decisions such as getting a mortgage or renting, investing in financial markets and planning for retirement; and life decisions such as going to college, getting married and having children. Some of these decisions have long-term implications while others have short- term implications (Guzman et al., 2019).

Otoritas Jasa Keuangan (2017) describes financial literacy as the extent to which skills, confidence and knowledge in financial institutions, their products and services, are described in a parameter. the description of the level of public knowledge about features, benefits and risks, rights and obligations as users of financial products and services is influenced by the explanation of the financial literacy index. Disclosure of financial literacy index is particularly important in giving a view to the level of 
public knowledge of the features, benefits and risks, rights and obligations as users of financial products and services. Financial literacy is considered important for a number of good reasons, namely consumers who have an understanding of financial literacy who can get through this financial difficult time, due to the fact that they may have savings, insurance, and investment diversification (Adam et al., 2017). Financial literacy also correlates with positive financial behavior, such as bills paid on time, loan installments, savings before they run out, and using credit cards wisely (Puneet Bhushan, 2013).

The rapid growth of financial literacy in Indonesia the last few years have received more attention, especially in developed countries. Based on Vitt (2004) financial literacy plays an important role in the financial decision-making process, because it is a systematic effort aimed at developing positive knowledge and attitudes.

Research in the field of household financial behavior has been widely studied, but very few studies have focused on aspects that make household financial management healthy and sustainable (Pandin et al., 2021). There are no studies linking financial behavior, financial literacy, financial planning, and household financial resilience with economic shocks and changes. The novelty of this research is a research model that links household financial resilience with financial planning, financial literacy, household behavior, and financial resilience. In addition to building the influence between variables, this study also strengthens the concept of household financial resilience.

\section{LITERATURE REVIEW}

\section{Financial Resilience}

Resilience spans several academic traditions, from engineering, to psychology, business studies through to work on adaptive ecologies and complexity science (Brassett \& Holmes, 2016). In policy terms, 'resilience agendas' have been deployed to manage systemic 'threats' as diverse as flood risk, terrorist attacks, ecological break- down (Brassett \& Holmes, 2016). Pandin et al., (2021) defines financial resilience as the ability to survive and cope with events in life that have an impact on a household's income and or assets. Financial resilience is the ability to recover more quickly from financial resilience is shaped by five capacities; robustness, anticipatory capacity, awareness, flexibility and recovery ability (Koning, 2015).

\section{Financial Planning}

Personal financial planning is a way to efficiently prepare household financial needs in the future (Lewis Altfest, 2004). Meanwhile, according to Murphy \& Yetmar (2010), personal financial management is the science and art of managing finances on an individual level. Thus, personal financial management includes two elements, namely knowledge of finance and the art of managing. The goal of characterizing complex financial planning behaviors is likely to require a complex, multidimensional model. Personal financial planning involves using savings to accumulate wealth, followed by careful use of wealth against depreciation and loss of value, and finally distribution of wealth over the course of the next life. (Boon et al., 2011). The plan reflects the individual circumstances when doing financial planning. The financial planning process progressively develops and builds a person's capacity to manage financial needs such as tax planning, credit and cash management, investment, insurance and risk management, and retirement planning (Boon et al., 2011).

\section{Financial Literacy}

Financial literacy is a person's ability and skill to utilize knowledge and apply financial concepts, consequently being able to confidently make the right personal 
financial decisions and effective financial planning so that it will provide prosperity. (Von Gaudecker, 2019). Financial literacy can be interpreted as financial knowledge, which aims to achieve prosperity (Lusardi \& Mitchell, 2014). A good understanding of financial management is a way out of various problems, including reducing poverty. The higher financial literacy will have an impact on welfare (Klapper \& Lusardi, 2020).

\section{Household Behaviour}

A household that is financially secure can contribute better to a vital community that is growing rapidly thus creating community economic development. Nofsinger \& Nofsinger (2010) defines financial behavior, namely studying how humans actually behave in a financial setting. Household financial behavior is closely related to household financial resilience. Resilient people have five main characteristics that can become behavior in the financial sector, namely positive, focused, flexible, structured and proactive. Consumption is not only influenced by a person's income level at a certain time, but also by historical factors and previous levels of consumption. Therefore, if the income received is lower than what is currently received, the person will find it difficult to change his lifestyle and level of consumption to a lower standard (Sun'an Muammil, 2017).

\section{Financial Literacy toward Financial Resilience}

Financial literacy often leads to positive financial behavior (Behrman et al., 2012). Someone with good financial literacy tends to better understand financial risks, have effective financial skills so that they will have better financial resilience. Pandin et al., (2021) defines financial resilience as the ability to survive and cope with events in life that have an impact on a household's income and or assets. However, if their financial knowledge is lacking, it will result in losses for the individual, both as a result of inflation and a decline in economic conditions at home and abroad (Yushita, 2017). Other studies have shown a more dynamic relationship between financial literacy and behavior, suggesting that the experience gained from using financial services contributes to making a person more financially literate (Lyons \& Kass-Hanna, 2018).

H1: Financial Literacy toward Financial Resilience.

\section{Financial Literacy toward Financial Resilience with Household Behaviour as Mediating Variable}

The relationship between financial literacy and household behavior is becoming important, individuals are increasingly being asked to be responsible for their financial well-being (van Rooij et al., 2012). The study includes a high level of awareness of financial literacy which has a positive influence on daily decisions and encourages higher savings rates which in turn improves the quality of life in the long term (Yushita, 2017). The relationship between financial literacy and household behavior is becoming more and more important, individuals are increasingly being asked to take responsibility for their financial well-being and their preparation for retirement (Lusardi \& Mitchell, 2007). Improper financial management will be very detrimental to a person and will likely be difficult to fix in the future. This is supported by research showing that having financial knowledge will cause problems in managing the household. This causes savings to be low and facing difficult financial conditions will have an impact on poor financial resilience (Yushita, 2017).

H2: Financial Literacy terhadap Financial Resilience with Household Behaviour as mediating variable.

\section{Financial Planning toward Financial Resilience}

Financial planning is definitely intended so that a person feels comfortable when facing unfavorable conditions (risk of inflation, recession, pandemic) and 
hopes for profit (Sealey, 1978). Financial planning is the process of achieving life goals, namely a prosperous and happy future through financial management (Sobaya et al., 2016). According to Sundjaja (2010) personal financial planning is the process of managing one's finances to achieve economic prosperity. The financial planning process can help individuals in controlling their financial condition. Each individual has different plans in planning their finances to achieve their respective financial goals.personal financial planning is a process of managing individual finances to achieve personal economic satisfaction. This planning process can assist individuals in controlling their financial condition. Every individual has different circumstances in planning their finances to achieve certain financial goals (Mendari \& Soejono, 2019). Personal financial planning is the process of managing money for personal economic satisfaction. Both financial satisfaction and personal satisfaction are the result of the personal financial planning process (Surendar \& Sarma, 2018). A good financial planner starts with applying a good financial attitude. Without adopting a good attitude in finance, it is difficult to have a financial surplus for future savings, let alone own investment capital (Yulianti \& Silvy, 2013).

H3: Financial Planning toward Financial Resilience.

\section{Financial Planning toward Financial Resilience with Household Behaviour as Mediating variable}

Kenyon (1914) stated that maintaining stable household finances requires careful household financial planning. This planning process can assist individuals in controlling their financial condition. Each individual, family has different circumstances so that in financial planning so as to meet certain needs and goals (Sundjaja, 2010). Determining this consumption pattern is a decision that can be taken from a person or group of people according to their view of life. This decision-making had a lot of influence. This influence can be in the form of internal factors of behavior, attitude to life, motivation, and financial planning (Oktavianti, 2017). Therefore, financial planning will determine household behavior and household consumption. Financial management errors will be very detrimental and difficult to fix in the future so that it will affect a person's financial resilience.

H4: Financial Planning terhadap Financial Resilience with Household Behaviour as mediating variable.

Based on literature rewiew, conceptual framework of this study can be described in Figure 1.

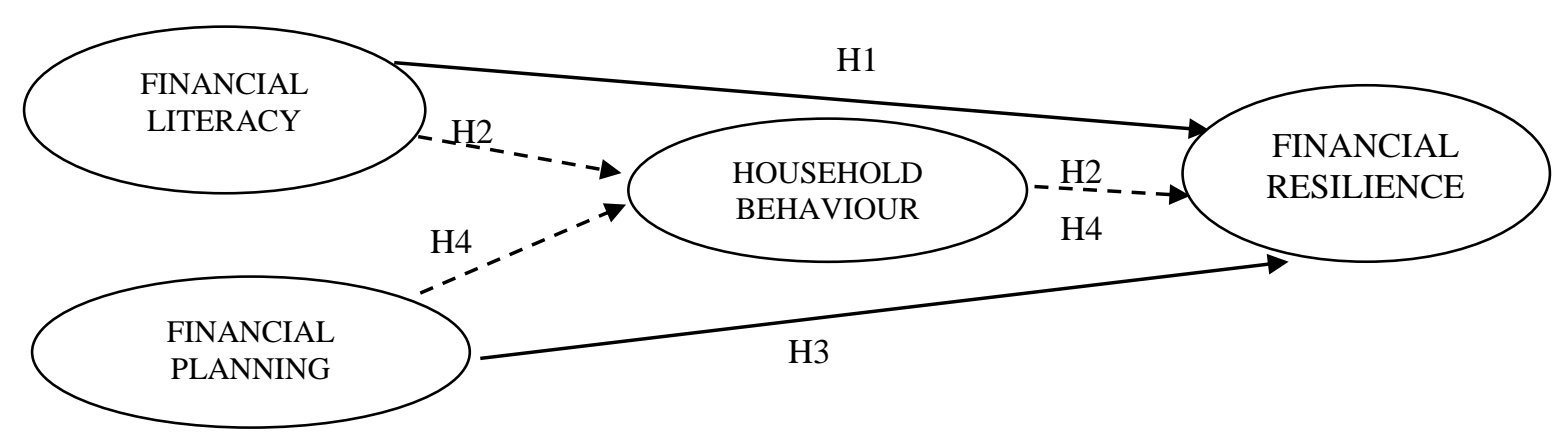

Figure 1. Conceptual Framework 


\section{RESEARCH METHODS}

This research is a social research that emphasizes a positivist approach so that it focuses on causality, careful empirical observation, and value-free research (Neuman, 2007). This study used an explanatory approach in which the existence of a variable can affect changes in other variables or a causal relationship occurs and must consider the direction of influence (Cooper \& Schlindler, 2014). This research is included in the category of quantitative research because it involves numerical data, measures objective facts, focuses on variables, and involves statistical analysis (Neuman, 2007). The purpose of quantitative research is testing the hypothesis (Neuman, 2014). The type of data used in this study is cross-sectional in which the type of data is used to capture a phenomenon at a certain time (Couper \& Schindler, 2006). The sample collection technique used was simple random sampling. The data was collected using an online survey involving 102 respondents. Variations in demographic data are presented in Table 1 .

The instrument to be used in this research is a questionnaire as a primary data collection method using number of question items with a specific format (Abdilah \& Jogiyanto, 2015). The format of the questionnaire chosen was a closed questionnaire by providing answers so that respondents were asked to choose between a series of answers given by the researcher (Neuman, 2014). The measurement scale used in the questionnaire is a Likert scale of 1 (strongly disagree) to 5 (strongly agree).

The questionnaire is divided into two parts. First, the questionnaire contains an introduction, informed consent and guarantees for privacy of respondents, filling procedures and general data that will be used to carry out descriptive analysis. Second, the questionnaire contains questions related to the research construct that reflect individual characteristics, attitude and behavior. All instruments used are an adaptation of previous studies which have been translated from English to Bahasa Indonesia.

Hypothesis testing is carried out in two stages. The first stage is testing the instrument by testing its validity and reliability. Validity testing uses construct validity by analyzing the results of outer loading and AVE. Meanwhile, the reliability test was tested using Cronbach alpha and composite reliability. After the instrument testing process is complete, the next stage is hypothesis testing. Hypothesis testing is tested by mediation testing. Hypothesis testing uses Smart PLS. Path analysis is an extension of multiple linear regression analysis, which tests the regression equation involving independent, dependent, and mediating constructs, both direct and indirect relationships through mediation (Ghozali, 2016).

\section{RESULT AND DISCUSSION}

\section{Result}

This study uses validity and reliability tests to measures the feasibility of the instrument. The validity test consists of the discriminat validity test. The discriminant validity test is declared good when the indicator of the construct has the highest loading value in its group or column (Hair et al., 2009). Based on the results of the validity test above, all the results of the convergent validity test showed the AVE value> 0.5 so that all constructs in the study were declared valid. The results of the validity test are presented in Table 2 Results of Validity Testing. 
Based on the reliability test results in Table 3, all validity test results show that the AVE value is more than 0.5 so that all constructs in the study are valid and can be used to carry out further testing. Meanwhile, when viewed from outer loading, the outer loading value of each construct shows the result> 0.5 . In this process, if the indicator has a construct of less than 0.5 then the indicator must be dropped.

Then, to measure reliability we are using composite reliability value exceeds 0.7 and using Cronbach alpha must be above 0.6 . The results of the reliability test are presented in Table 3 Results of Reliability Testing. Based on the results of reliability testing, it can be seen that the composite reliability value on the research variable is above 0.7 , while financial resilience has the highest composite reliability value while financial planning has the lowest composite reliability value. If you review the results of the Cronbach alpha value is in the financial resilience variable.

The inner model can be evaluated by looking at r-square for the dependent construct. The higher the r-square value, the better the prediction model of the proposed research model. Based on the rsquare value in Table 4 shows that financial literacy and financial planning is able to explain the variability of household behavior construct amounted to $22.2 \%$, and the remaining $77.8 \%$ was explained by other constructs outside investigated in this study. Meanwhile, household behavior is able to explain the variability of the financial resilience construct by $32.7 \%$, and the remaining $67.3 \%$ is explained by other constructs outside those studied in this research.

Based on the results of the test procedure of the relationship between variables with SmartPLS 3.0 in table 5, we get the following results. Testing relationships between variables of direct influence as well as indirect influence, as discussed in the previous section of this article. As presented in Figure 2, the probability value ( $p$-value) for all models is below the limit value of 0.05 or $5 \%$ (Hair et al., 2009). Based on hypothesis 1, it is known that the effect of financial literacy on financial literacy is not supported with path estimate $=-0.224, \mathrm{t}$ value $=1.867$, and $p$-value $<0.05$. The results of hypothesis 2 the effect of financial literacy on financial resilience $(\beta$ $=0.221$ decreases to $\beta=0.114$ ) and when compared with the effect of financial literacy on financial resilience with household behavior as a mediator, the results are path Next estimate $=0.160$, $\mathrm{t}$ value $=3.143$, and $p$-value $<0.05$, it is declared significant. Therefore, if you look at the two results, it indicates full mediation. Hypothesis 3 states that financial planning on financial literacy is not supported with path estimate $=0.171$, $\mathrm{t}$-value $=1.158$, and $\mathrm{p}$-value $<0.05$. The results of hypothesis 4 the effect of financial literacy on financial resilience $(\beta$ $=0.221$ decreases to $\beta=0.114$ ) and when compared with the effect of financial literacy on financial resilience with household behavior as a mediator the results are path Next estimate $=0.160$, tvalue $=3.143$, and $p$-value $<0.05$, it is declared significant. Therefore, if you look at the two results, it indicates full mediation. 
Table 1. Profile of Respondents

\begin{tabular}{|c|c|c|c|}
\hline \multirow{2}{*}{ Characteristic } & \multirow{2}{*}{ Description } & \multicolumn{2}{|c|}{ Distribution } \\
\hline & & Frequency & Percentage \\
\hline \multirow[t]{2}{*}{ Sex } & Male & 32 & $31 \%$ \\
\hline & Female & 70 & $69 \%$ \\
\hline Education & Senior High School & 10 & $10 \%$ \\
\hline \multirow[t]{4}{*}{ Background } & Diploma & 5 & $5 \%$ \\
\hline & Bachelor & 45 & $44 \%$ \\
\hline & Master & 30 & $29 \%$ \\
\hline & Doctor & 12 & $12 \%$ \\
\hline \multirow[t]{6}{*}{ Occupation } & $\begin{array}{l}\text { Government employees/ } \\
\text { Indonesian military army/police }\end{array}$ & 30 & $29 \%$ \\
\hline & Private employees & 24 & $24 \%$ \\
\hline & Student & 12 & $12 \%$ \\
\hline & Teacher & 16 & $16 \%$ \\
\hline & Entrepreneurs & 10 & $10 \%$ \\
\hline & The others & 10 & $10 \%$ \\
\hline \multirow[t]{4}{*}{ Income per month } & $<\operatorname{Rp} 1,000,000$ & 22 & $22 \%$ \\
\hline & Rp 1,000,000-Rp 5,000,000 & 30 & $29 \%$ \\
\hline & $\operatorname{Rp} 5,000,000-\operatorname{Rp} 10,000,000$ & 30 & $29 \%$ \\
\hline & $>\operatorname{Rp} 10,000,000$ & 20 & $20 \%$ \\
\hline \multirow{4}{*}{$\begin{array}{l}\text { Expenditure per } \\
\text { month }\end{array}$} & $<\mathrm{Rp} 1,000,000$ & 22 & $22 \%$ \\
\hline & Rp 1,000,000-Rp 5,000,000 & 30 & $29 \%$ \\
\hline & $\operatorname{Rp} 5,000,000-\operatorname{Rp} 10,000,000$ & 20 & $20 \%$ \\
\hline & $>\operatorname{Rp} 10,000,000$ & 30 & $29 \%$ \\
\hline
\end{tabular}

Table 2. Validity Test

\begin{tabular}{ccccc}
\hline Variable & Indicator Valid & Outer Loading & AVE Value & Conclusion \\
\hline Financial Literacy & FL2 & 0.924 & 0.574 & Valid \\
& FL3 & 0.937 & & \\
& FL6 & 0.553 & & \\
\hline \multirow{2}{*}{ Financial Planning } & FL10 & 0.511 & & Valid \\
& FP1 & 0.841 & 0.638 & \\
& FP2 & 0.807 & & \\
& FP4 & 0.836 & & \\
& FP5 & 0.867 & & \\
\hline Household Behaviour & HB3 & 0.617 & & \\
& HB4 & 0.701 & 0.525 & \\
& HB5 & 0.709 & & \\
& HB7 & 0.729 & & \\
& HB8 & 0.664 & & \\
& HB9 & 0.651 & & \\
\hline Financial Resilence & HB11 & 0.831 & & \\
& FR1 & .857 & & \\
& FR2 & .939 & & \\
\hline
\end{tabular}


Table 3. Reliability testing

\begin{tabular}{lccl}
\hline \multicolumn{1}{c}{ Variable } & Composite Reliability & Cronbach Alpha & Conclusion \\
\hline Financial Literacy & 0.872 & 0.759 & Reliable \\
Financial Planning & 0.802 & 0.893 & Reliable \\
Household Behaviour & 0.916 & 0.849 & Reliable \\
Financial Resilence & 0.959 & 0.771 & Reliable \\
\hline
\end{tabular}

Table 4. R Square

\begin{tabular}{ccc}
\hline Variable & R square & Adjusted R Square \\
\hline Financial Resilience & 0.222 & 0.197 \\
Household Behaviour & 0.327 & 0.313 \\
\hline
\end{tabular}

Table 5. Estimates for Direct and Indirect Effect

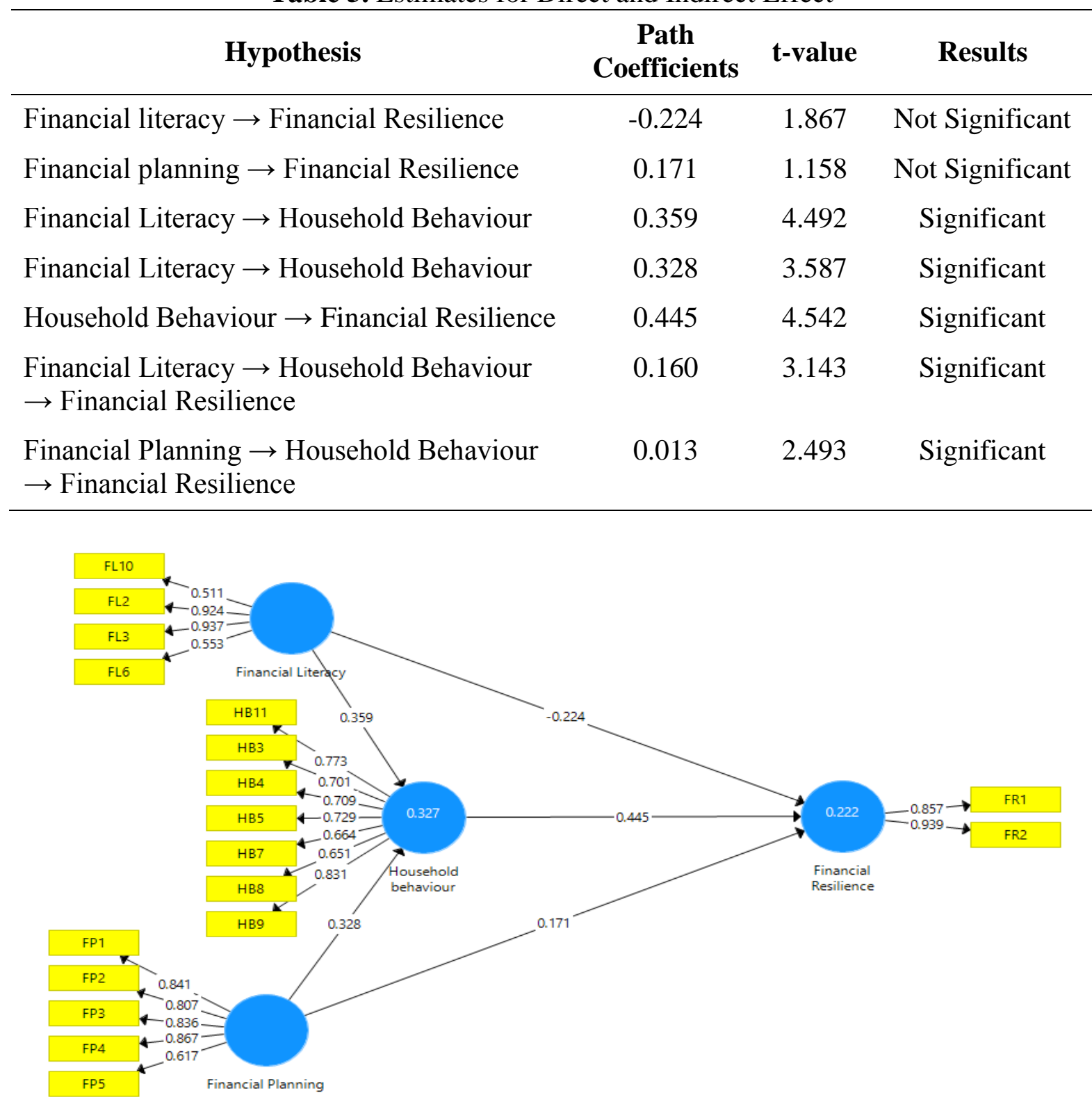

Figure 2. Data Processing Results 


\section{Discussion}

Financial literacy is an important issue at all income levels. Based on the research results, the first hypothesis which states that financial literacy has an effect on financial resilience is not supported. This means that good financial literacy but not applied to everyday life will not have an impact on financial resilience. During the Covid-19 pandemic, financial literacy is actually needed for low-income or underprivileged groups to get support services such as financial counseling by helping individuals develop savings goals, save money, control finances, and plan for inheritance (Hira, 2005). However, due to government policies that limit people's activities to work and activities, literacy with a limited amount of income will still result in poor financial resilience conditions.

Furthermore, in hypothesis 2 it is stated that financial literacy on financial resilience with household behavior as mediation is supported. This is because if one's literacy skills are able to be applied and able to control household behavior by reducing consumption, controlling finances and saving, then financial resilience will have a good impact. Based on this, a simple lifestyle is something that must be done during the Covid-19 pandemic.

The third hypothesis which states that financial planning has an effect on financial resilience is not supported. Money planning can be defined as a comprehensive evaluation of a person's current salary and future financial situation using currently known variables to predict income, asset value, and future withdrawal plans. Making arrangements for our cash can be classified as a comprehensive assessment of a person's current salary and future monetary situation using current known factors to anticipate future wages, resource prices and withdrawal plans
(Netemeyer et al., 2018). Good financial planning for future conditions will also be able to increase a person's resilience during a pandemic.

Meanwhile, hypothesis 4 which states that financial planning has an effect on financial resilience with household behavior as a mediator is supported. Good financial planning by regulating financial posts in a disciplined manner then applied in non-wasteful household behavior will have a positive impact on financial resilience during a pandemic. The financial planning process is an initial stage that needs to be done so that the amount of expenditure and income can be calculated in detail. After that it takes discipline to implement the planning in daily activities.

The empirical implication of this research is that few studies have focused on aspects that make household financial management healthy and sustainable (Pandin et al., 2021). Through research, it has added variations to the findings of financial resilience research studies in Indonesia's fluctuating economic conditions. Meanwhile, the practical implication of this research is that efforts to increase community financial resilience in facing economic changes can be done by increasing public financial literacy and knowledge to have good financial planning so that it will lead to household behavior which will eventually increase community financial resilience.

The limitation of this research is that the research mediation only uses household behavior to mediate the effect of financial literacy and financial planning on financial resilience, while there are many other factors that might be other mediators. In addition, the distribution of the sample is only dominated by people living in Java, so it requires research with a larger number of samples. 


\section{CONCLUSION}

Based on the research that has been done, there are two accepted hypotheses and two rejected hypotheses. The supported hypothesis is hypothesis 2 which states the effect of household behavior mediation on financial literacy and financial resilience. This is because the financial literacy process without the discipline to change simple household behavior will not have an impact on good financial resilience during a pandemic. In addition, hypothesis 4 states that the effect of household behavior mediation on financial planning and financial resilience is supported. Support for this hypothesis occurs because the financial planning process has been able to be harmonized with household financial behavior, resulting in good financial resilience.

The future research agenda of this research is expected to use a questionnaire as a data collection method so that other methods such as experiments and qualitative methods can be used to deepen the concepts of financial resilience, household behavior, financial planning and financial literacy.

\section{REFERENCES}

Abdillah, W. \& Hartono,J. (2011). Partial Least Square. Andi Yogyakarta : Yogyakarta

Adam, A. M., Frimpong, S., \& Boadu, M. O. (2017). Financial literacy and financial planning: Implication for financial well-being of retirees. Business and Economic Horizons, 13(2), 224-236. https://doi.org/ 10.15208/beh.2017.17

Barbera, C., Jones, M., Korac, S., Saliterer, I., \& Steccolini, I. (2017). Governmental financial resilience under austerity in Austria, England and Italy: How do local governments cope with financial shocks? Public Administration, 95(3), 670-697. https://doi.org/10.1111/padm.12350
Behrman, B. J. R., Mitchell, O. S., Soo, C. K., \& Bravo, D. (2012). How Financial Literacy Affects Household Wealth Accumulation Author ( $s$ ): Jere R . Behrman, Olivia S. Mitchell , Cindy K. Soo and David Bravo Source: The American Economic Review, MAY 2012, Vol. 102 , No. 3, PAPERS AND PROCEEDINGS OF THE One Hun. 102(3), 300-304.

Bieri, D. S. (2014). Conceptualizing Financial Resilience. October.

Boon, T. H., Yee, H. S., \& Ting, H. W. (2011). Financial literacy and personal financial planning in Klang Valley, Malaysia. International Journal of Economics and Management, 5(1), 149-168.

Brassett, J., \& Holmes, C. (2016). Building resilient finance?: Uncertainty, complexity, and resistance. British Journal of Politics and International Relations, 18(2), 370-388. https:// doi.org/10.1177/1369148115615028

Cooper, D. R., Schindler, P. S., \& Sun, J. (2006). Business research methods (Vol. 9, pp. 1-744). New York: Mcgraw-hill.

Firdaus, G. (2018). Increasing Rate of Psychological Distress in Urban Households: How Does Income Matter? Community Mental Health Journal, 54(5), 641-648. https://doi.org/10.1007/s10597-0170193-9

Ghozali,I. (2016). Konsep,Teknik dan Aplikasi Menggunakan Program SmartPLS 3.0.Semarang : Badan Universitas Diponegoro

Guzman, ,IF., Paswan, A., \& Tripathy, N. (2019). Consumer centric antecedents to personal financial planning. Journal of Consumer Marketing, 36(6), 858-868. https://doi.org/ 10.1108/JCM-01-2018-2514

Hair, J. F. (2009). Multivariate data analysis. 
Hakim, F. A., Sunarti, E., \& Herawati, T. (2014). Manajemen Keuangan dan Kepuasan Keuangan Istri pada Keluarga dengan Suami Istri Bekerja. Jurnal Ilmu Keluarga Dan Konsumen, 7(3), 174-182. https://doi.org/ 10.24156/jikk.2014.7.3.174

Hira, T. K. (2005). Understanding the Impact of Employer-Provided Financial Education on Workplace Satisfaction. 39(1), 173-194.

Kenyon, D. B. L. M. B. (1914). Family Financial Management - Planning for the Future. College of Agriculture and Life Sciences, University of Arizona (Tucson, 15-16.

Klapper, L., \& Lusardi, A. (2020). Financial literacy and financial resilience: Evidence from around the world. Financial Management, 49(3), 589-614.

https://doi.org/10.1111/fima.12283

Koning, F. M. de. (2015). Financial Resilience: Research on financial resilience at Dutch local government in times of austerity. August, 1-70.

Lewis Altfest. (2004). Personal Financial Planning: Origins, Developments and a Plan for Future Direction. The American Economist, 48(2), 53-60.

Lusardi, A., \& Mitchell, O. S. (2007). Baby Boomer retirement security: The roles of planning, financial literacy, and housing wealth. Journal of Monetary Economics, 54(1), 205224.

https://doi.org/10.1016/j.jmoneco.200 6.12.001

Lusardi, A., \& Mitchell, O. S. (2014). The economic importance of financial literacy: Theory and evidence. Journal of Economic Literature, 52(1), 5-44. https://doi.org/ $10.1257 /$ jel.52.1.5
Lyons, A., \& Kass-Hanna, J. (2018). Financial Inclusion, Financial Literacy and Economically Vulnerable Populations in the Middle East and North Africa. SSRN Electronic Journal, June. https:// doi.org/10.2139/ssrn.3189563

Mendari, A. S., \& Soejono, F. (2019). Hubungan Tingkat Literasi dan Perencanaan Keuangan. Modus Journals, 31(2), 227-240.

Murphy, D. S., \& Yetmar, S. (2010). Personal financial planning attitudes: A preliminary study of graduate students. Management Research Review, 33(8), 811-817. https:// doi.org/10.1108/01409171011065617

Netemeyer, R. G., Warmath, D. E. E., Fernandes, D., \& Jr, J. G. L. (2018). How Am I Doing? Perceived Financial Well-Being, Its Potential Antecedents, and Its Relation to Overall Well-Being. Journal of Consumer Research, 45(May), 68-89. https://doi.org/10.1093/jcr/ucx109

Neuman, L. W. (2007). Social research methods, 6/E. Pearson Education India.

Lawrence Neuman, W. (2014). Social Research Methods: qualitative and quantitative approaches.

Nofsinger, J. R., \& Nofsinger, J. R. (2010). Social Mood and Financial Economics Social Mood and Financial Economics. Journal of Behavioral Finance, 6(May 2013), 37-41.

Oktavianti, H. (2017). Perilaku Konsumsi Rumah Tangga Dan Pengaruhnya Terhadap Kebijakan Makro Ekonomi Kabupaten Bangkalan. Media Trend, 12(1).

https://doi.org/10.21107/mediatrend.v $12 \mathrm{i} 1.2728$

Otoritas Jasa Keuangan. (2017). Strategi Nasional LiterasiKeuangan Indonesia (Revisit 2017). Otoritas Jasa Keuangan, 1-99 
Pandin, M. Y. R., Ratnawati, T., \& Yuhertiana, I. (2021). The Influence of Financial Structure, Financial Literacy and Financial Behavior on Household Financial Resilience Using Financial Inclusion and Financial Decision as Interverning Variables on Cancer Survivor s Household in East Java During Covid-19 Pandem. IJEBD (International Journal of Entrepreneurship and Business Development), 04(01), 80-90.

Puneet Bhushan, Y. M. (2013). Financial Literacy and its Determinants. International Journal of Engineering, Business and Enterprise Applications, 13, 155-160.

Sealey, C. W. (1978). Financial Planning with Multiple Objectives. Financial Management, $\quad 7(4), \quad 17$. https://doi.org/10.2307/3665081

Sobaya, S., Hidayanto, M. F., \& Safitri, J. (2016). Pengaruh literasi keuangan dan lingkungan sosial terhadap perencanaan keuangan pegawai di universitas islam indonesia yogyakarta. Madania, 20(01), 1-14.

Suarez, L. R. (2015). center for global development essay Emerging Market Macroeconomic Resilience to External Shocks : Today versus Pre Global. Center For Global Development.

Sun'an Muammil, H. A. (2017). Household Consumption Behaviour in Ternate Indonesia. Russian Journal of Agricultural and Socio-Economic Sciences, 12(December), 239-245.

Sundjaja, A. M. (2010). Perencanaan Keuangan untuk Mencapai Tujuan Finansial. ComTech: Computer, Mathematics and Engineering Applications, 1(1), 183. https:// doi.org/10.21512/comtech.v1i1.2218

Surendar, G., \& Sarma, V. V. S. (2018). Financial Literacy and Financial Planning Among Teachers of Higher Education. International Journal of Pure and Applied Mathematics, 118(18), 1627-1649.
Susilo, A., Rumende, C. M., Pitoyo, C. W., Santoso, W. D., Yulianti, M., Herikurniawan, H., Sinto, R., Singh, G., Nainggolan, L., Nelwan, E. J., Chen, L. K., Widhani, A., Wijaya, E., Wicaksana, B., Maksum, M., Annisa, F., Jasirwan, C. O. M., \& Yunihastuti, E. (2020). Coronavirus Disease 2019: Tinjauan Literatur Terkini. Jurnal Penyakit Dalam Indonesia, 7(1), 45. https://doi.org/10.7454/jpdi.v7i1.415

van Rooij, M. C. J., Lusardi, A., \& Alessie, R. J. M. (2012). Financial Literacy, Retirement Planning and Household Wealth. Economic Journal, 122(560), 449-478.

https://doi.org/10.1111/j.1468-

0297.2012.02501.x

Vitt, L. a. (2004). Consumers' Financial Decisions and the Psychology of Values. Journal of Financial Service Professionals, 58(November), 68-77. http://search.ebscohost.com/login.asp $\mathrm{x}$ ?direct $=$ true $\& \mathrm{db}=\mathrm{bth} \& \mathrm{AN}=1488895$ 2\&site $=$ ehost-live

Von Gaudecker, H.-M. (2019). American Finance Association How Does Household Portfolio Diversification Vary with Financial Literacy and Financial Advice? Author ( $\mathrm{s}$ ): HANS-MARTIN VON GAUDECKER Source: The Journal of Finance, Vol . 70 , No . 2 ( APRIL 2015 ), pp . 489-507 Publishe. The Journal of Fianance, 70(2), 489-507.

Yulianti, N., \& Silvy, M. (2013). Sikap Pengelola Keuangan Dan Perilaku Perencanaan Investasi Keluarga Di Surabaya. Journal of Business and Banking, 3(1), 57-68.

Yushita, A. N. (2017). Pentingnya Literasi Keuangan Bagi Pengelolaan Keuangan Keluarga. Journal Nominal, VI, 11-26. 